\title{
Extratropical Cyclones and Precipitation within the Canadian Archipelago during the Cold Season
}

\author{
MATTHEW R. INTIHAR ${ }^{1}$ and RONALD E. STEWART ${ }^{2}$
}

(Received 22 November 2002; accepted in revised form 27 September 2004)

\begin{abstract}
Extratropical cyclones produce much of the precipitation over the Arctic, but the details of this cause-effect relationship are not well documented. In this study, we examined extratropical cyclones within the Canadian Archipelago, a subregion of the Arctic, over the period 1948-97. Using data from the Historical Canadian Climate Data (HCCD), the U.S. National Climate Center (UNCC), and the European Meteorological Bulletin (EMB), we assessed the relationship between extratropical cyclones and cold-season snowfall (October-April) for 10 events at each of 11 surface stations within the region. These events were relatively brief ( $72 \mathrm{~h}$ or less), but resulted in precipitation totals that exceeded the average monthly amount. At each station, within the 10 most extreme precipitation months of the 50-year study period, we often found a single event that accounted for approximately one-third of the total snowfall in that month. For sites located in the southeastern Archipelago, eventrelated storms typically approached from the southeast, whereas southwestern sites were affected by southwesterly storms, and northwestern sites, by northwesterly storms. In many cases, cyclone dissipation occurred within 24 h of the event's conclusion. Precipitation analyses in this study were considerably affected by snowfall undercatchment; the magnitude of this effect needs further examination in future studies. However, the identification of extreme events and related storm tracks appears to be relatively unaffected by the lack of corrected precipitation data.
\end{abstract}

Key words: precipitation, snowfall, extratropical, cyclones, storms, winter, Canadian, Archipelago

RÉSUMÉ. Les cyclones extratropicaux sont responsables d'une grande partie des précipitations dans l'Arctique, mais les détails de cette relation de cause à effet ne sont pas bien documentés. Nous nous penchons, dans cette étude, sur les cyclones extratropicaux au sein de l'archipel Canadien, une sous-région de l'Arctique, au cours de la période allant de 1948 à 1997 . À l'aide de données tirées de la Base de données climatiques historiques du Canada (HCCD), du National Climate Center (UNCC) américain et du Bulletin Météorologique Européen (BME), on a évalué la relation entre les cyclones extratropicaux et les chutes de neige en saison froide (d'octobre à avril) pour 10 événements s'étant produits à chacune de 11 stations de surface dans la région. Ces événements avaient une durée relativement courte ( $72 \mathrm{~h}$ ou moins), mais ils provoquaient des précipitations totalisant plus que la moyenne mensuelle. À chaque station, au cours des 10 mois de précipitations les plus intenses sur les 50 ans de la période d'étude, on a souvent trouvé un seul événement qui comptait pour environ un tiers du total de l'apport neigeux pour ce mois. Pour les emplacements situés dans la partie sud-est de l'archipel, les tempêtes reliées aux événements venaient d'ordinaire du sud-est, tandis que ceux du sud-ouest étaient touchés par les tempêtes dues aux vents du sud-ouest, et ceux du nord-ouest, par les tempêtes dues aux vents du nord-ouest. Dans bien des cas, le cyclone se dissipait dans les $24 \mathrm{~h}$ suivant la fin du phénomène. Dans cette étude, les analyses de précipitations étaient considérablement influencées par une sous-estimation de l'apport neigeux; il faudrait étudier plus à fond l'importance de cet effet dans des recherches ultérieures. L'identification d'événements extrêmes et des trajectoires de tempêtes qui y sont associées semble relativement insensible au manque de données hyétométriques rectifiées.

Mots clés: précipitations, chute de neige, extratropical, cyclones, tempêtes, hiver, canadien, archipel

Traduit pour la revue Arctic par Nésida Loyer.

\section{INTRODUCTION}

The water cycle over the Arctic has received increasing attention over the last decade or two because of the need to understand the consequences of a changing climate at high latitudes. Precipitation within the Arctic climate is an important variable in determining these consequences, since it is an intrinsic aspect of the water cycle. Nonetheless, many of the mechanisms responsible for precipitation production within the Arctic have not been studied in great detail.

The Canadian Archipelago (Fig. 1) is a unique component of the Arctic system, since moisture flux patterns in this region are quite different from those occurring over

\footnotetext{
${ }^{1}$ Department of Earth and Space Science, York University, 4700 Keele Street, Toronto, Ontario M3J 1P3, Canada; present address: 3071116 Street NW, Edmonton, Alberta T6J 3T2, Canada; m_intihar@hotmail.com

${ }^{2}$ Department of Atmospheric and Oceanic Sciences, McGill University, 805 Sherbrooke Street West, Montreal, Quebec H3A 2K6, Canada
}

(C) The Arctic Institute of North America 


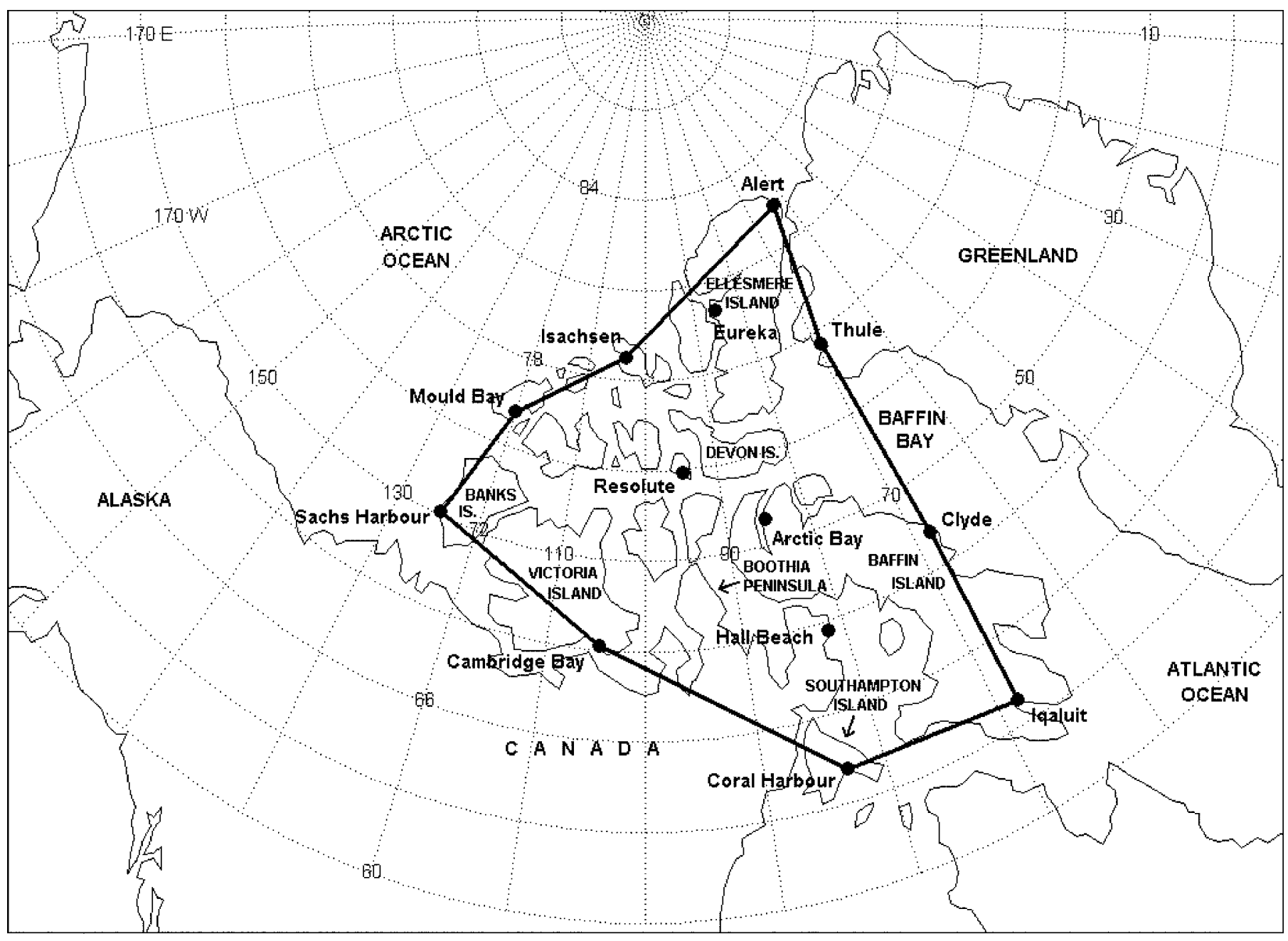

FIG. 1. Map of the Canadian Archipelago. The 11 stations used in this study, along with Coral Harbour and Thule, are marked with black dots.

other northern latitudes. Bromwich (1997), using the European Centre for Medium-Range Weather Forecasts Re-Analysis (ERA) information, concluded that between 1980 and 1995, moisture transport over the Arctic occurred via two alternating regimes. Both regimes involved a counterclockwise flow of moisture around the pole, but the centre of the vortex alternated between the North Atlantic Ocean and the Russian side of the Arctic Ocean. Within each regime, a large difference was observed between the Canadian Arctic and other Arctic regions. For most of the Archipelago, a southward-directed meridional water vapour flux component was observed as opposed to the northward component over all other high-latitude areas. Specifically, Serreze et al. (1995) determined that, along the $70^{\circ} \mathrm{N}$ latitude circle, southward mean meridional water vapour fluxes were found between $130^{\circ} \mathrm{W}$ and $70^{\circ}$ W. This influx of water vapour from over the Arctic Ocean, combined with moisture supplied by the Pacific and Atlantic oceans, suggests that this island-dominated region may be a large sink of water vapour. Knowledge of the mechanisms responsible for the occurrence of precipitation is essential for understanding how this pattern evolves.
Precipitation data over the Arctic as a whole are relatively sparse. Studies of general precipitation characteristics using the available information have been conducted by, for example, Burns (1973, 1974), Bryazgin (1976), Maxwell (1980, 1982), and AES (1986). According to Bryazgin (1976), annual values over the Canadian Archipelago vary considerably, from $150 \mathrm{~mm} /$ year along the Arctic Ocean coastline to $600 \mathrm{~mm} /$ year near Iqaluit. A study of long-term precipitation trends over Canada, including its northern regions, found a modest increase (about $2.5 \%$ per decade) in precipitation north of $55^{\circ} \mathrm{N}$ for the period 1948-95 (Mekis and Hogg, 1999). None of the above studies, however, examined precipitation on a smaller scale, within individual events.

The production of precipitation over the Arctic is influenced by several factors. These include radiation, convection, orography, and extratropical cyclones. Radiative cooling can contribute to the generation of instability and is often linked with light precipitation, particularly in the summertime when widespread stratus clouds are present (Curry et al., 1996). Convection can occur over the Arctic during the summer, but over the Archipelago it is almost never severe and essentially does not occur in the cold season. 


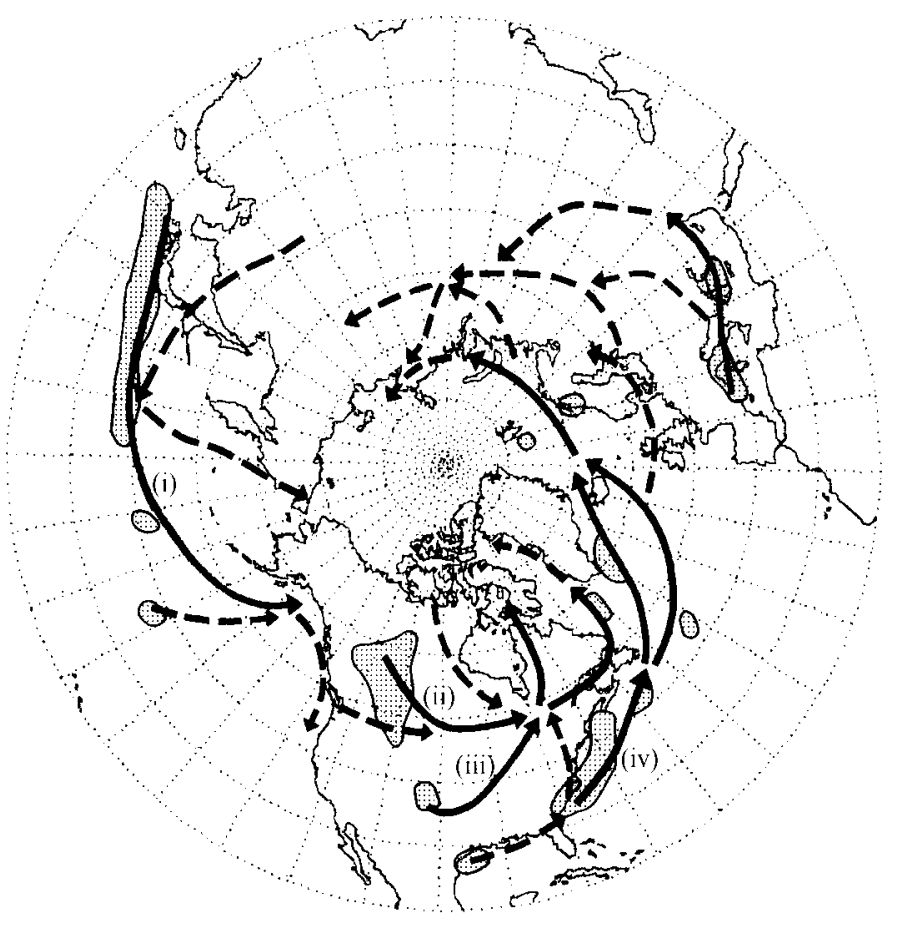

FIG. 2. Primary (solid) and secondary (dashed) cyclone tracks and areas of principal cyclogenesis (stippled) in the month of January for the years 1958-77 (from Whittaker and Horn, 1984). The primary storm tracks most likely to affect the Canadian Archipelago are labeled as (i) the Pacific storm track, (ii) the Alberta lee cyclone track, (iii) the Colorado lee cyclone track, and (iv) the Eastern United States storm track.

Orography has a more significant influence on precipitation in the Arctic. Its effects are very notable along the Scandinavian coast where, for example, amounts in excess of $1000 \mathrm{~mm} /$ year have been recorded (Bryazgin, 1976). In general, patterns of orographically induced precipitation in the Arctic are not well understood. As Woo et al. (1983) stated, one reason for this poor understanding is that observational data from land stations often underestimate this factor, since land stations are usually at sea level and precipitation amounts tend to increase with altitude on windward sides of mountains. It is difficult to simulate these orographic effects. For example, using the National Centers for Environmental Prediction/National Center for Atmospheric Research (NCEP/NCAR) reanalysis information described by Kalnay et al. (1996), Serreze and Maslanik (1997), and Bromwich (1997) found that the modeled orographic effects over northern Europe were severely underestimated.

The last factor, synoptic-scale extratropical cyclones, is very important for precipitation production. Cyclone activity over the North Atlantic is common, particularly in wintertime, and is often associated with low atmospheric pressure at the surface near Iceland. High values of precipitation consequently occur over southeastern Greenland, near the associated storm track (Serreze, 1995). Serreze et al. (1993) found that the distribution of mean monthly central surface pressure of Arctic cyclones was periodic, with a minimum in December $(990 \mathrm{hPa})$ and a maximum in May (1000 hPa).
Whittaker and Horn (1984) performed an extensive study on cyclone frequency, cyclogenesis, and storm tracks in the Northern Hemisphere between 1958 and 1977. For the four mid-season months examined (January, April, July, and October), they found that cyclone frequency over the central Arctic was highest in July, with more than 20 cyclones present per month.

Regions of Northern Hemisphere cyclogenesis (cyclonic storm development) are quite consistent throughout the year (Whittaker and Horn, 1984). The preferred regions include Alberta, Colorado, southern Japan, the eastern seaboard of the United States, and southeastern Greenland. All these areas lie outside the Canadian Archipelago.

During the winter, however, some of the ensuing storm tracks over North America can influence the Canadian Archipelago. Whittaker and Horn (1984) documented all major storm tracks occurring over the Northern Hemisphere from 1958 to 1977 (Fig. 2). They indicated the presence of several primary storm tracks (indicated by solid lines) that could affect the North American continent. These are the Pacific storm track (i), which advects cyclones towards Alaska from the southwest; the Alberta (ii) and the Colorado (iii) storm tracks, which bring systems from the lee of the Rocky Mountains to eastern Canada and northward into the eastern Archipelago; and the Eastern United States track (iv), which advects storms from the eastern seaboard to the northeast around the eastern shores of Greenland. Of the four, the Pacific, Alberta, and Colorado tracks have the greatest potential to influence the Canadian Archipelago.

The relationship between cyclones and precipitation within the Archipelago has been examined to some degree by various authors. It is apparent from these studies that different Arctic and Subarctic regions of Canada exhibit significantly different synoptic patterns during high precipitation events. Bradley and England (1979) found that within the Queen Elizabeth Islands, large precipitation amounts at Alert were most often accompanied by a Baffin Bay surface low, whereas precipitation events at Isachsen were related to a western Archipelago/eastern Arctic Ocean low. Variable low-pressure positions were also observed during high precipitation events on Baffin Island (Barry et al., 1975), with the associated low center located anywhere from the Boothia Peninsula in the west to Baffin Bay in the east. A similar study of the Mackenzie Basin (Lackmann and Gyakum, 1996) found that most intense precipitation periods were accompanied by a strong low over the Gulf of Alaska and lee cyclogenesis over Alberta.

The addition of storm track information to the location of surface lows was touched on in several studies (Alt, 1978, 1979, 1987; Alt and Bourgeois, 1995) that examined summer ice cap mass balances within the Archipelago in relation to extratropical cyclone location and migration. Over the Queen Elizabeth Islands, polar-frontal systems were responsible for considerably more summer precipitation and ice cap growth than quasi-stationary Baffin Bay lows. This was apparent to some degree on the Devon Ice 
Cap, located on Devon Island, but to a much greater degree on the Meighen Ice Cap, located along the Arctic Ocean coastline near Isachsen (Alt, 1987). On the Agassiz Ice Cap, located on Ellesmere Island near Alert, precipitation was high for storm systems propagating from the northwest over the Arctic Ocean. However, a more westerly/ southwesterly track was favoured for the Queen Elizabeth Islands as a whole. This storm track was oriented along the land/ocean boundary from northern Alaska to the northern Archipelago, where large horizontal temperature differences between the land and open water supported such large-scale disturbances. Given that the Archipelago surface is uniform in the cold season, this track applies only to the summer months.

\section{OBJECTIVES}

As described above, the characteristics of extratropical cyclones over the Arctic as a whole have been documented to some degree. However, little work has been done to relate these storm systems to precipitation in any great detail, particularly on a more regional scale. An understanding of this relationship has several applications, among them forecasting precipitation, assessing the regional water balance, and contributing to climate change studies.

Consequently, our objective in this study is to describe some of the relations between extratropical cyclones and precipitation within the Canadian Archipelago, specifically within the cold season (October-April). We further restricted the focus to those storm systems associated with high snowfall episodes because of their direct application to forecasting and the major contributions they make to regional precipitation. Specifically, we examined the 10 most anomalously high precipitation events at each of 11 Archipelago stations, ensuring that each event contained only frozen precipitation. Station precipitation totals and occurrence reports, as well as surface isobaric and upperair height contour data from archived synoptic-scale charts, were used to perform the analysis.

\section{DATA SOURCES}

We used archived daily synoptic-scale charts to obtain data on the location and movement of extratropical cyclones over the Canadian Archipelago. The U.S. National Climate Center (UNCC) provided two maps for each day within the period 1948-70. One was an isobaric (sea-level pressure) analysis, and the other a plot of $500 \mathrm{hPa}$ height contours. Maps produced from January 1957 onwards were plotted at 1200 UTC, while those prior to 1957 were staggered in time, with surface charts plotted at 1230 UTC and upper-air charts at 1500 UTC. The European Meteorological Bulletin (EMB), available for most of the remaining years (1976-97), provided similar information for all regions north of $30^{\circ} \mathrm{N}$ latitude. The EMB used $0000 \mathrm{UTC}$ data to plot these charts between January 1976 and March 1991, and 1200 UTC data from April 1991 onwards.

We obtained precipitation totals for 11 stations in the Canadian Archipelago (Fig. 1) from the Historical Canadian Climate Database (HCCD) (Gullett et al., 1992). This data set contains both six-hourly and monthly precipitation totals, as well as hourly or three-hourly reports of precipitation occurrence and type. For six-hourly precipitation, the time intervals used were 0000-0600, 0600$1200,1200-1800$, and 1800-0000 UTC. Archives for each station varied in range, but in most cases, both sixhourly and monthly data were available over the 1948-97 time period. The main exceptions were Arctic Bay, with only 18 years (1948-66) of available precipitation data, and Isachsen, with only 30 years $(1948-78)$.

Precipitation totals over the region were recorded using both ruler measurements and Nipher gauges. Snowfall depths determined by ruler were converted to water-equivalent values by assuming a snowfall density of $100 \mathrm{~kg} \mathrm{~m}^{-3}$, whereas Nipher gauges measured the meltwater amount directly from the collected snowfall. Six-hourly snowfall totals at Arctic Bay and Isachsen were determined exclusively by ruler measurement, but for the remaining nine stations, Nipher gauges were implemented in January 1963 (Cambridge Bay), 1964 (Eureka, Mould Bay, Resolute, Clyde, and Iqaluit), and 1965 (Alert, Sachs Harbour, and Hall Beach) and were used for the remainder of the 50year period.

For the most part, our analysis of precipitation was performed using the original HCCD precipitation archives. As noted by previous authors (e.g., Metcalfe et al., 1994; Mekis and Hogg, 1999; Louie et al., 2002), both undercatchment and overcatchment errors are present within this data set. These errors are the result of several factors, including snow density variability, wind, gauge wetting losses, evaporation, and the exclusion of trace six-hourly values from precipitation totals. For the 1953-95 time period, Mekis and Hogg (1999) developed a revised data set that attempted to correct for these factors. This data set contains all the stations in the present study except Arctic Bay and Isachsen. Mean coldseason-precipitation increased by $129 \%$ from the original to the revised data set, with undercatchment predominating at all nine stations. Measurements taken prior to Nipher gauge use increased by $71 \%$, as opposed to $147 \%$ for those taken afterwards, indicating different amounts of undercatchment for different techniques.

Despite the general tendency towards underestimation of precipitation over the Archipelago, overcatchment is also a factor. This source of error is due to blowing snow, a relatively common phenomenon in the Arctic (Stewart et al., 1995). Examination of hourly and three-hourly reports of blowing snow (archived from January 1953 onwards) during event periods showed that 73 of the 99 post-1952 events coincided with reports of blowing snow. This result suggests that precipitation overcatchment did take place during most events, but the relative impact on measured precipitation during the event periods is not known. 
Event duration errors are also difficult to assess. Hourly to three-hourly precipitation occurrence reports were used as an aid in defining the end points of the events. As a result, the average error was $\sim 2 \mathrm{~h}$, as long as the non-zero six-hourly precipitation amounts during the events were not exclusively caused by blowing or drifting snow, which could shorten the events or divide them into multiple parts. This assumption may only be valid in some cases, given the prevalence of blowing snow over the region.

\section{IDENTIFICATION OF EVENTS}

\section{Periods of High Snowfall Amounts}

Within the next two sections, we describe our use of these data sets to relate extratropical cyclones to coldseason precipitation over the Archipelago. As mentioned, this assessment was twofold. The first step was to isolate specific periods in which unusually high snowfall amounts occurred at each station. The second was to examine these periods for the presence of extratropical cyclones.

Initially, we examined general spatial trends of coldseason precipitation over the Archipelago using the Mekis and Hogg (1999) revised data set. We found that between October and April, the total amount of snowfall was lowest near the Arctic Ocean coastline at Eureka $(46 \mathrm{~cm})$ and Mould Bay $(62 \mathrm{~cm})$. Values steadily increased from northwest to southeast, reaching maximum values at Hall Beach $(150 \mathrm{~cm})$, Clyde $(153 \mathrm{~cm})$, and in the extreme southeast, Iqaluit $(255 \mathrm{~cm})$. The lowest monthly averages were usually found in February, increasing in a similar fashion from $6 \mathrm{~cm}$ at Eureka to $28 \mathrm{~cm}$ at Iqaluit, while the maximum averages, in October, varied from $12 \mathrm{~cm}$ at Eureka to $53 \mathrm{~cm}$ at Iqaluit. Examining cold-season months within the period of record, the lowest maximum monthly total was also observed at Eureka, with $31 \mathrm{~cm}$ recorded in October 1955 . The highest maximum monthly amount of $243 \mathrm{~cm}$ occurred at Clyde in April 1977, followed by $170 \mathrm{~cm}$ at Clyde in November 1982 and $119 \mathrm{~cm}$ at Iqaluit in October 1968.

\section{High Precipitation Events}

Using six-hourly precipitation data from the HCCD, we subsequently divided the archived precipitation into isolated "events." An event was defined as a period of snowfall during which no consecutive trace or zero six-hourly precipitation amounts were found. We chose anomalously high precipitation events for further analysis, under the assumption that they would have a greater impact on the water cycle within the region.

To identify the extremely high precipitation events, we determined precipitation averages for each month and used them to create four new "monthly" averages, one for each quarter of the month, so that the median date of the quarter was used as the median date in the new averages. A ratio of total event precipitation to the corresponding "monthly" average, defined as the precipitation anomaly index (PAI), was then calculated for each cold season event. Thus, a value of 1.0 would indicate that event precipitation equaled the amount normally produced in a one-month period at that time of year. Given that corrected six-hourly values were not available, we decided to use the corresponding uncorrected monthly averages in comparisons with six-hourly data. It was felt that any measurement errors would largely offset one another if both elements of the PAI ratio were uncorrected, thus making the corresponding PAI values as accurate and as meaningful as possible. Also, for any given PAI value, the six-hourly and monthly values were taken from the same station during the same month. Therefore, the factors that contributed to measurement errors, and therefore the magnitudes of the errors, were likely to be similar for both parameters.

As an additional assessment, we recalculated PAIs for all events at nine stations using corrected monthly precipitation totals in place of the uncorrected values. In this second calculation, the magnitude of the PAIs decreased on the order of $50 \%$, but 79 of the original 90 extreme events were still selected. This result suggests that the original analysis was effective at determining the most extreme events, despite uncertainties in their magnitudes.

In this study, we have limited the focus to the 10 events with the highest PAI for each site, for a total of 110 events (Tables 1 and 2). This sample size allowed us to document characteristics of the events and the associated stormtracks, as well as the variability of these characteristics at individual stations and across the Archipelago.

\section{Features of High Precipitation Events}

For each event selected, the event snowfall total (PE, in $\mathrm{mm}$ ), duration (D, in $\mathrm{h}$ ), and PAI value were determined using the HCCD archives. Results for Alert, Eureka, Isachsen, Mould Bay, Sachs Harbour, and Resolute are shown in Table 1, and those for the remaining stations in Table 2. The highest PAI for each station ranged from 1.8 at Iqaluit to 5.6 at Clyde; all 110 events had values of 1.0 or larger, with an average lower limit of $\sim 1.5$. Like the total cold-season precipitation, event snowfall totals gradually increased from northwest to southeast from $4 \mathrm{~cm}$ at Eureka (February 1965) to $76 \mathrm{~cm}$ at Clyde (April 1977). Event duration also increased towards the southeast, from $4 \mathrm{~h}$ at Isachsen (February 1949, December 1962) to $168 \mathrm{~h}$ at Iqaluit (March 1962).

Figure 3 shows the average event precipitation $(\mathrm{mm})$ and event duration (h) for each station. Both sets of averages also increase from northwest to southeast. Precipitation averages range from $7 \mathrm{~cm}$ at Mould Bay to $33 \mathrm{~cm}$ at Iqaluit and $35 \mathrm{~cm}$ at Clyde, while the corresponding duration averages vary from $24 \mathrm{~h}$ at Mould Bay to $84 \mathrm{~h}$ at Iqaluit. The main exception to the general northwest-tosoutheast increase is Alert, which recorded higher average precipitation $(19 \mathrm{~cm})$ and average duration (70 hours) of extreme events than most other stations. As discussed 


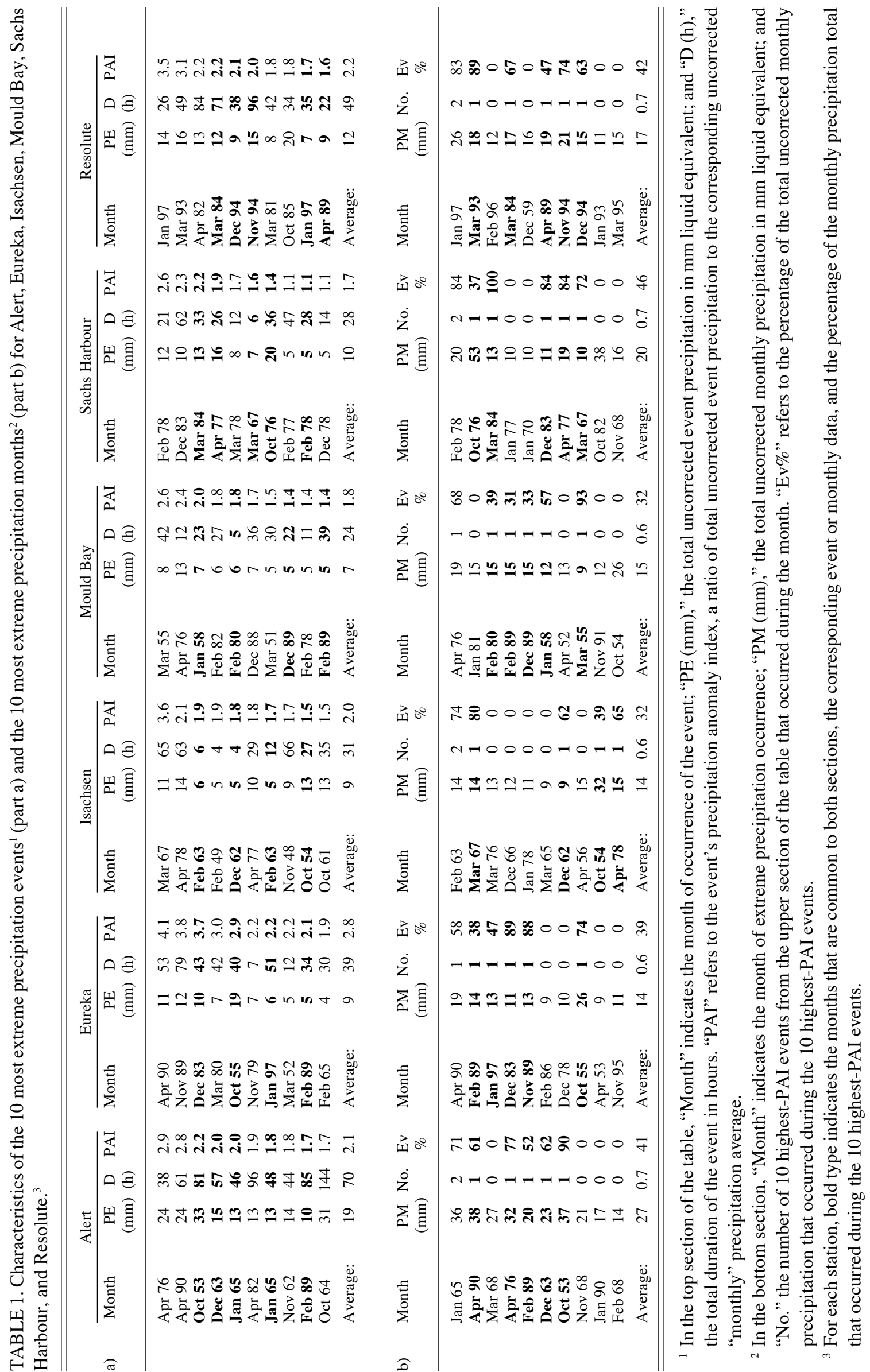


later, this exception may occur because sub-synopticscale processes contribute substantially to precipitation at this location.

Of the 110 events, the majority (92) lasted $72 \mathrm{~h}$ or less. These relatively short-lived events were most common in central and western parts of the Archipelago. As shown in Tables 1 and 2, all 10 events at Isachsen, Mould Bay, Sachs Harbour, and Cambridge Bay were less than $72 \mathrm{~h}$ in duration, as were nine of the 10 events at Eureka, Hall Beach, and Arctic Bay. However, only six such events occurred at Clyde and five at Iqaluit. Both event duration and precipitation amount tended to be highest at these two locations, gradually decreasing across the Archipelago to Eureka and the Arctic Ocean coastline.

The two main exceptions to this trend were Arctic Bay and Alert. At Arctic Bay, near Clyde in the southeast, low values were found for both event duration and precipitation amount. An example is the February 1963 event, which lasted only $6 \mathrm{~h}$ and produced only $5 \mathrm{~cm}$ of snow. Low values at Arctic Bay may have arisen because only 18 years of data were available, limiting the likelihood of high-precipitation events. At Alert, in the extreme northern part of the Archipelago, exceptionally high values were found: events averaged $19 \mathrm{~cm}$ total precipitation and $70 \mathrm{~h}$ duration. Of the 11 stations, only Clyde $(35 \mathrm{~cm})$ and Iqaluit $(33 \mathrm{~cm})$ had events with greater average total precipitation, and only Iqaluit ( $84 \mathrm{~h}$ ) had higher average event duration. Again, this localized effect may be due to the enhancement of precipitation through mechanisms other than extratropical cyclones.

The large range of event durations $(4-168 \mathrm{~h})$ may be due in part to the speed of motion of the event-related extratropical cyclones. Analysis of storm tracks showed that lower average event durations $(24-39 \mathrm{~h})$ corresponded to average cyclone speeds of $39-43 \mathrm{~km} / \mathrm{h}$ at sites near the Arctic Ocean coastline (Eureka, Isachsen, Mould Bay, and Sachs Harbour), except at Alert (70 h, $31 \mathrm{~km} / \mathrm{h})$. Events at most sites farther to the south and east (Resolute, Cambridge Bay, Arctic Bay, Hall Beach, and Clyde) had higher durations $(33-57 \mathrm{~h})$ and slower average cyclone speeds $(30-33 \mathrm{~km} / \mathrm{h})$, with the exception of Iqaluit $(84 \mathrm{~h}, 37 \mathrm{~km} / \mathrm{h})$. At Alert, synoptic effects may have been less significant than at other locations, but at Iqaluit, it is not clear why the values differ from those at neighbouring stations. It is possible that Iqaluit, being closest to the warm, moist Gulf Stream regions, experienced storms that were less removed from this moisture source and so had a greater horizontal extent of precipitation-bearing cloud. Thus, despite relatively fast-moving storm systems, snowfall could still result over a considerable length of time.

\section{Importance of Individual Events}

To estimate the importance of individual events, we then compared months with high-PAI events and months with extreme precipitation amounts. Using uncorrected monthly data, we calculated the average monthly precipitation at each station for each of the seven coldseason months. Uncorrected information was used because the corrected data were not available for the entire 50 -year period at any of the 11 sites. Also, since event PAI values were calculated using uncorrected data, comparisons between high-PAI event months and months with extreme precipitation totals would be more meaningful if based on the same data set.

Using the monthly averages calculated above, we converted each monthly precipitation total within the period of record at each station into a percentage anomaly. The 10 months at each station with the highest percentage anomalies, i.e., the 10 most extreme precipitation months, are shown in Tables 1 and 2. Also shown for each month are the total monthly precipitation, the number of the 10 highest-PAI events found within the month, and the percentage of the monthly precipitation that occurred during those events. We compared these months to the 10 highestPAI months for each station to assess the significance of individual high-PAI events on high precipitation amounts over relatively long periods of time.

The example of January 1965 at Alert will show more clearly how these values were derived. The average uncorrected monthly precipitation at Alert for the month of January is $7.0 \mathrm{~mm}$ (water-equivalent). During January $1965,36.1 \mathrm{~mm}$ was recorded, as shown under "PM (mm)" in the lower section of Tables 1 and 2 . This value is $416 \%$ higher than the average, the highest anomaly observed at Alert. Therefore, January 1965 is the first month listed for Alert. The list of extreme-PAI events for Alert in the upper section of Tables 1 and 2 shows two events in January 1965; a value of two is thus entered under "No." During these two events, a total precipitation of $25.8 \mathrm{~mm}$ was reported, which is $71 \%$ of the monthly value of $36.1 \mathrm{~mm}$. This percentage is shown in the last column of the lower section, under "Ev\%."

The distribution of high and low values for snowfall totals in the extreme precipitation months was similar to that for event snowfall totals. Monthly precipitation totals were lowest in the northwestern Archipelago/Arctic Bay $(14-15 \mathrm{~mm})$ and highest at Clyde $(51 \mathrm{~mm})$ and Iqaluit $(83 \mathrm{~mm})$. The minimum value of $9 \mathrm{~mm}$ was found at Eureka, Isachsen, and Mould Bay, and the maximum of 169 mm occurred at Clyde in April 1977, the same location and month in which the two highest-PAI events occurred.

The number of event-containing extreme precipitation months per station was relatively consistent: between five and six for eight Archipelago stations. The relative contribution of the 10 highest-PAI events to the monthly precipitation was also quite consistent, ranging from $32 \%$ to $46 \%$ for the same eight stations. Two of the three exceptions occurred at Cambridge Bay and Iqaluit, where events were found within only three of the 10 months, contributing only $16 \%$ to $20 \%$ of the overall precipitation. High-PAI events may be less significant for monthly precipitation at these sites because of their more southerly location. These sites are usually closer to the jet stream and are therefore influenced by a greater 


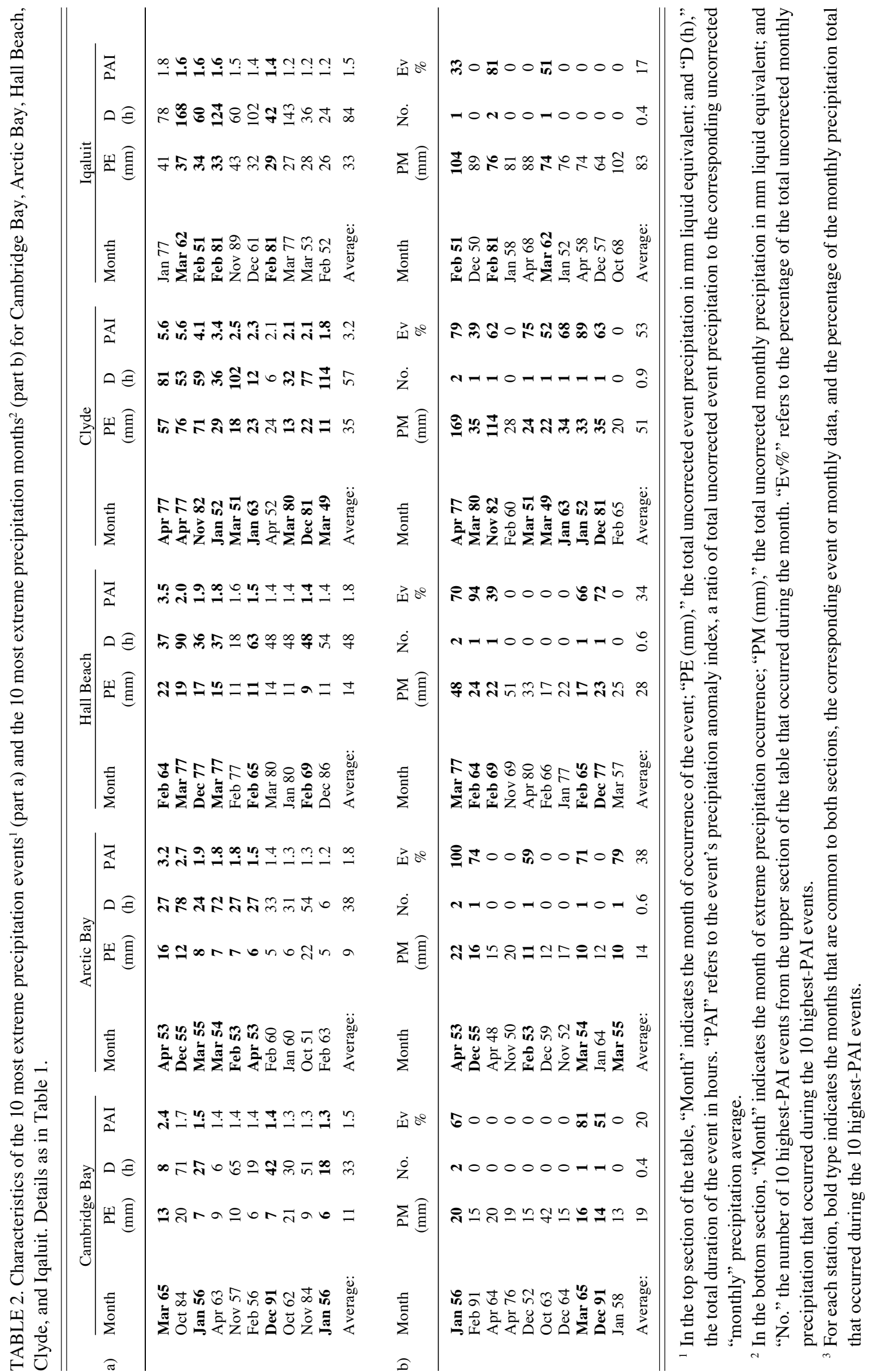




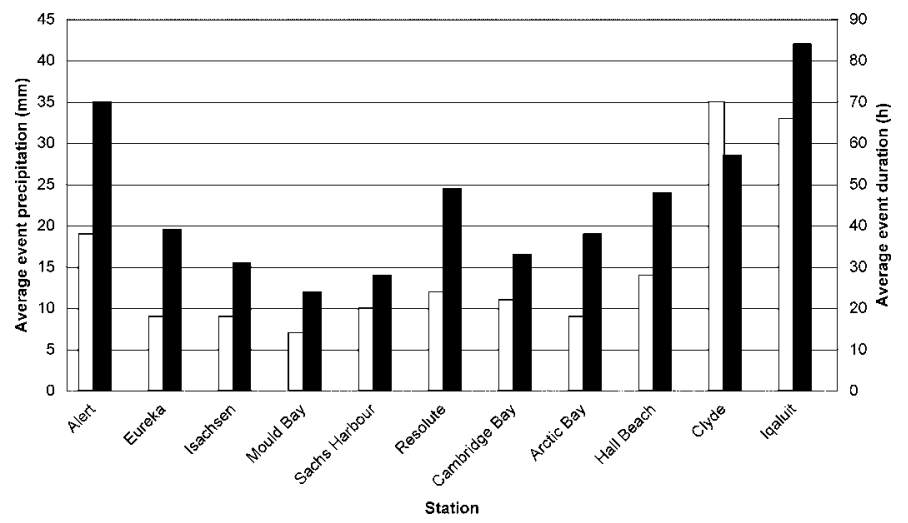

FIG. 3. Average event precipitation ( $\mathrm{mm}$, in white) and average event duration (h, in black) for each of the 11 stations.

number of extratropical cyclones per month than the more northerly stations in the Archipelago. Having a greater number of events per month reduces the impact of individual events on the overall monthly precipitation at these stations. The results at a third southern Archipelago site, Hall Beach, were inconclusive in this regard. With near-average values for five event-containing months and $34 \%$ event-related precipitation, data at this station neither supported nor refuted this hypothesis.

The third exception occurred at Clyde, where events were found within 8 of the 10 extreme precipitation months, accounting for over half of the total precipitation (53\%). As shown in the following section, this exceptional situation may be due to the tendency for storm systems to become occluded (forced aloft from the earth's surface by the convergence of cold and warm fronts) and dissipate over Baffin Bay. Such systems become quasi-stationary over the region and consequently produce substantial precipitation for some locations. Thus a tendency towards extremely high or low snowfall amounts could exist, depending on the proximity of the storm system to the station. Further evidence of the potential for unusually high event precipitation is the comparatively large PAI values of the events at Clyde. The tendency for event precipitation to be either substantial or marginal would increase the relative significance of high-PAI events in the overall monthly precipitation.

Overall, we found that 59 of the 110 extreme precipitation months contained at least one high-PAI event, and nine of these months contained two such events. As well, we estimated that $36 \%$ of all precipitation in the selected months occurred during a high-PAI event. These results illustrate that high-PAI events are a significant component of extreme precipitation months.

\section{ANALYSIS OF ASSOCIATED EXTRATROPICAL CYCLONES}

Once we had identified and analyzed the highest-10PAI events, we focused on determining their relationship to nearby synoptic-scale disturbances. For this assessment, we used both surface analyses and $500 \mathrm{hPa}$ height contour plots provided in the UNCC and EMB archives to determine the relevant storm tracks for each event:

1. We determined the time of the highest six-hourly precipitation total within the event.

2. We located the extratropical cyclone pertaining to this event on the surface isobaric chart nearest in time to the six-hourly precipitation maximum, defining the cyclone as the low-pressure center that was closest to the event station.

3. We then examined the two surface charts plotted immediately before and after the original surface chart to identify all low-pressure centers within $1500 \mathrm{~km}$ of the original low.

4. To determine which low on each surface chart corresponded to the original low, we examined the corresponding $500 \mathrm{hPa}$ height contour charts for local maxima in height contour gradients. We made two assumptions: (1) that patterns illustrated on the $500 \mathrm{hPa}$ charts closely resemble those found at the level of the jet stream (at roughly $300 \mathrm{hPa}$ ) because surface friction has only a minimal effect on wind vector orientation at these levels (Holton, 1992), and (2) that surface extratropical cyclones tend to propagate along the jet stream. Thus we could determine storm tracks by locating a lowpressure center on a given surface chart, finding the same location on the corresponding $500 \mathrm{hPa}$ map, and moving upstream/downstream along the $500 \mathrm{hPa}$ height contours until we located a low-pressure center on the earlier/later surface chart.

We continued this iterative process until the storm track had been determined from $24-48 \mathrm{~h}$ before the event's beginning until 24-48 h after its conclusion. We included the segments before and after the event to provide further information on the origin and departure of the event cyclones.

Using the above method, we determined the storm tracks of all event-related extratropical cyclones. Composite storm track plots for four of the stations (Isachsen, Alert, Cambridge Bay, and Clyde) are shown in Figure 4. Dots on these plots indicate the location of the surface lowpressure center every $24 \mathrm{~h}$ from $24-48 \mathrm{~h}$ before the start of an event until $24-48 \mathrm{~h}$ after its conclusion, unless cyclogenesis (cyclone development) occurred less than $24 \mathrm{~h}$ before event onset, or cyclolysis (cyclone dissipation) within $24 \mathrm{~h}$ of event termination. In those cases, the first dot indicates the location of the low-pressure center $0-24 \mathrm{~h}$ before the event began, or the last dot indicates the location $0-24 \mathrm{~h}$ after the event ended. These tracks are indicated with a T-junction at one end of the storm track.

Occasionally, an event in Tables 1 and 2 was associated with two surface extratropical cyclones instead of only one, 
one cyclone passing over or near the event station before the other cyclone. This occurred in 13 of the 110 events studied. Several examples of this scenario are shown in Figure 4. In this set of diagrams, we used the same colour for both cyclone tracks, but indicated each low-pressure center for the second cyclone with an open oval.

Using the boundary sections in Figure 1 as a guide, we classified storm systems as entering the Archipelago from the north/northwest (Thule-Sachs Harbour), southwest (Sachs Harbour-Coral Harbour), or southeast (Coral Harbour-Thule). Specifically, we determined the point of entry according to which of these three boundary sections the surface low-pressure center crossed. The point of exit was determined in a similar way. For some events, the center of the storm system did not cross any of the boundary sections, remaining outside the region for the duration of the event. In these cases, we defined the points of entry and exit as the boundary section closest to the low-pressure center at the beginning and end of the event.

These criteria had to be modified for extratropical cyclones that formed or dissipated within $24 \mathrm{~h}$ of the start or end of the event. Depending on which type of evolution occurred, an entry or exit point was not recorded. Instead, we classified the case as one of either cyclogenesis or cyclolysis, regardless of where the low-pressure center was located in relation to the Archipelago.

The largest number of all event-related storms (48) entered the region across the southeast boundary, followed by 45 across the southwest boundary, and 27 across the north/northwest boundary. The exit point distribution was considerably more skewed, with the majority of storms (60) exiting the region through the southeastern boundary. In addition, 23 exited to the north/northwest and 16 to the southwest.

We also found that the extratropical cyclone entry point was usually near the event site. Hall Beach, Clyde, and Iqaluit in the southeast were all predominantly affected by storms that entered through the southeastern boundary. Similarly, Sachs Harbour and Cambridge Bay (southwest) were affected most often by southwesterly storms, and Isachsen (northwest) by northwesterly storms. The only exceptions were at Mould Bay (northwest), where event system origin was roughly evenly distributed, and Alert (north), which was mainly associated with southeasterly storms. No distinct patterns were found at two of the three inland sites (Arctic Bay and Eureka), but Resolute, like Cambridge Bay, was usually affected by southwesterly storms.

Over all events, a greater number of cyclones entered the Archipelago (120) than exited (99) because cyclolysis was more common than cyclogenesis over the region. Only three instances of cyclone formation occurred within 24 h of event onset: one southwest of Cambridge Bay in the lee of the Western Cordillera, a second over the central Archipelago, and the third over Davis Strait. In contrast, 24 systems ( $\sim 20 \%$ of entering systems) dissipated within $24 \mathrm{~h}$ of the event conclusion. The locations of cyclolysis varied, with nine over Baffin Bay, seven over the central Archipelago, six over the Arctic Ocean, and two over the main land mass to the southwest. These data strongly suggest a tendency for extratropical cyclones to dissipate over the region. This dissipation coincides with an occlusion process, during which cyclones become quasi-stationary as they move away from the jet stream (Holton, 1992).

Not all sites within the Archipelago are affected to the same degree by extratropical cyclones. For example, as discussed in the previous section, the event precipitation amount and duration were both relatively high at Alert. However, during seven of the 10 highest-PAI events at this site, the nearest surface low-pressure center remained at least $600 \mathrm{~km}$ away (Fig. 4b). Such results imply that extratropical cyclones play a relatively small role in directly producing high-PAI events at Alert. Other mechanisms, such as orographic uplift, must play a greater role.

\section{SUMMARY}

This study has examined some of the relations between extratropical cyclones and snowfall within the Canadian Archipelago over the 1948-97 period, in particular during the cold season (October-April). Some of the findings are described below and schematically illustrated in Figure 5.

Like other researchers, we found that the amount of snowfall during the cold season varies substantially across the Archipelago. Total cold season amounts calculated from the corrected data set differ by a factor of five, from $46 \mathrm{~cm}$ at Eureka to $255 \mathrm{~cm}$ at Iqaluit. As well, monthly values are typically lowest in February and highest in October.

In this study, we selected high-precipitation events during the cold season for further investigation, examining the 10 events with the highest precipitation anomaly index (PAI) values at each of the 11 sites. All of the PAI values for the 110 events were 1.0 or higher, indicating that each event total was equal to or greater than the average precipitation recorded within a one-month period at the station. Actual values ranged from 1.0 to as high as 5.6.

These 110 events account for a significant portion of high-precipitation months within the Archipelago. At each station, we determined the 10 cold-season months with the most ex treme precipitation totals. We found that more than half of these months contained at least one high-PAI event, with such events accounting for $\sim 36 \%$ of the total 110 month snowfall. That is, heavy precipitation on the monthly scale is often a consequence of one (or more) extreme events.

High-PAI events within the Archipelago are primarily associated with extratropical cyclones. These storm systems approach the Archipelago from the northwest, southwest, or southeast. In general, these storms have a greater effect on sites located near their point of entry to the Archipelago. This fact also implies that the storms become 


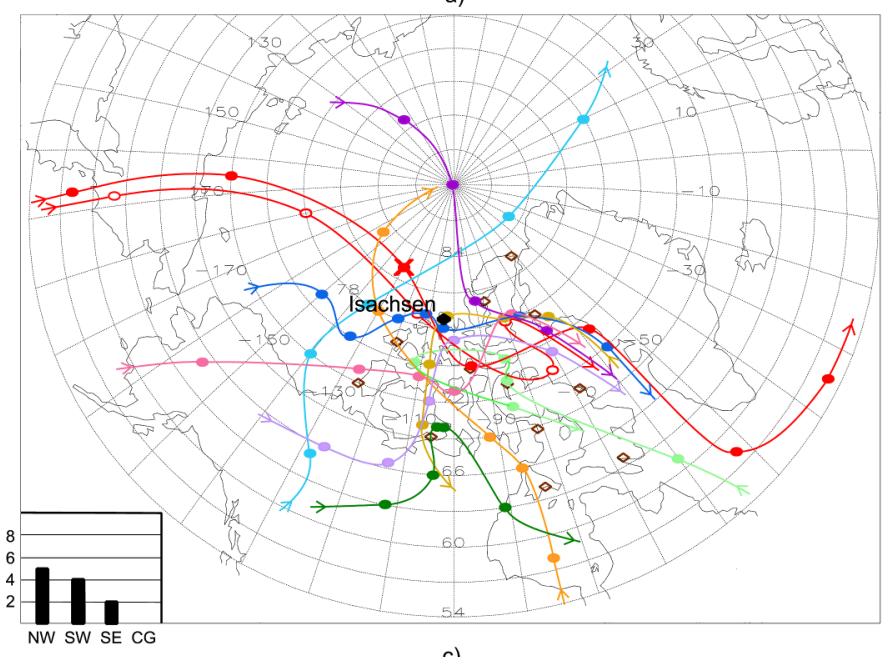

c)

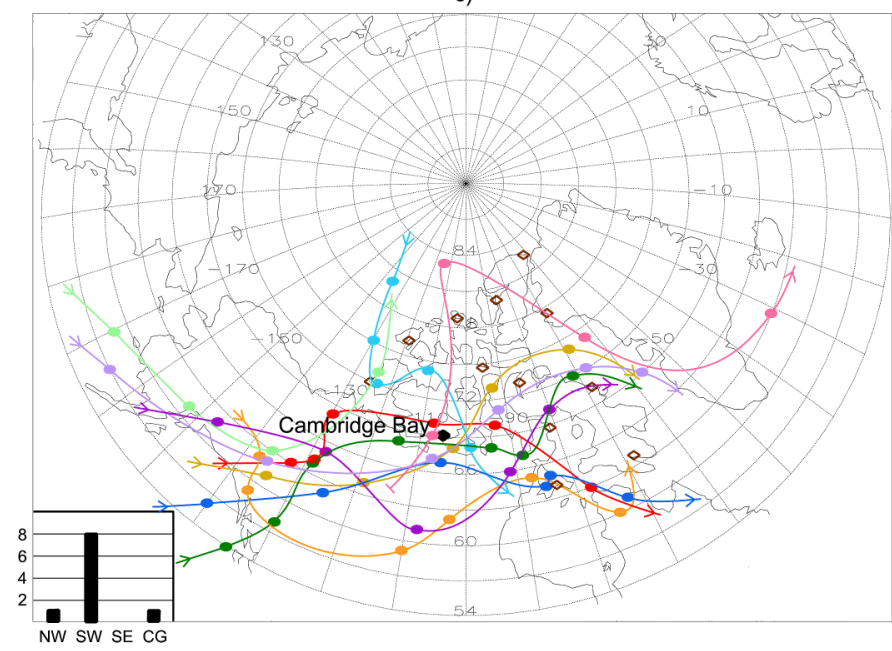

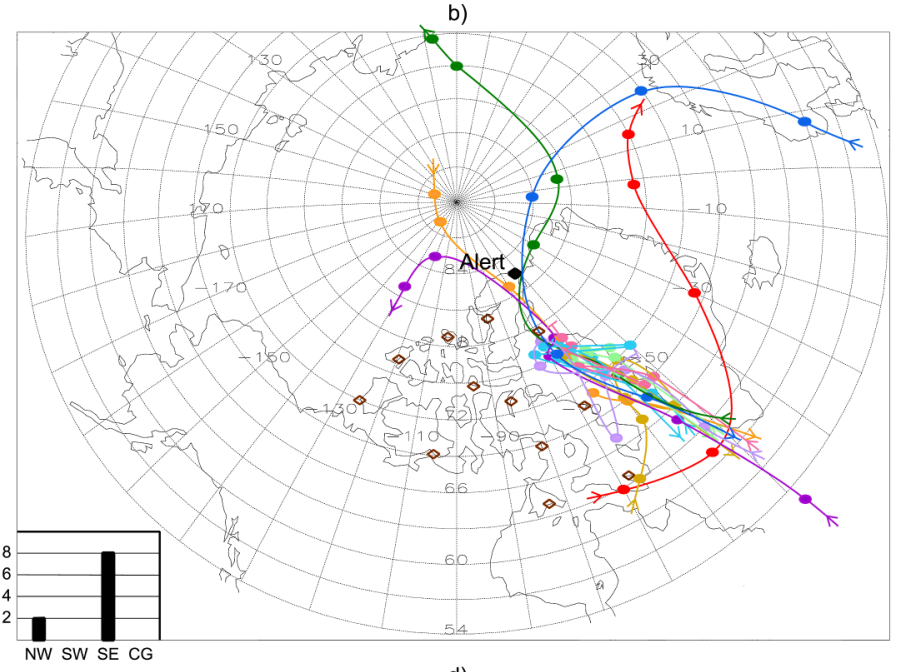

d)

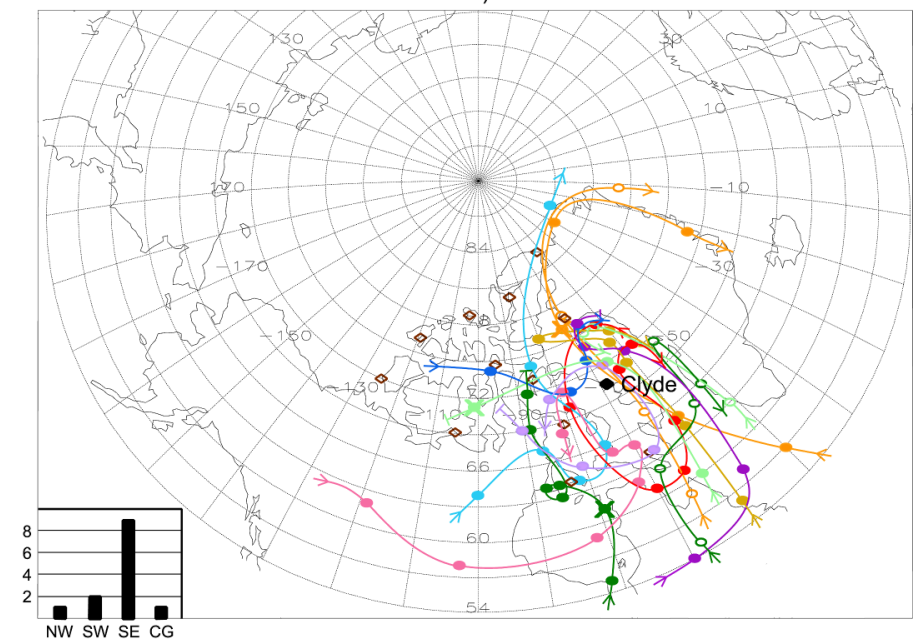

FIG. 4. Tracks of extratropical cyclones during precipitation events for (a) Isachsen, (b) Alert, (c) Cambridge Bay, and (d) Clyde, showing positions of the lowpressure center every $24 \mathrm{~h}$ (solid ovals). If two cyclones were present during an event, the low-pressure centers for the second cyclone are denoted by open ovals. An ' $\mathrm{X}$ ' indicates the position of the first system at the time of emergence of the second system. Tracks beginning or ending with a T-junction indicate cyclone formation or dissipation within $24 \mathrm{~h}$ of the start or end of an event. The remaining paths begin and end $24-48 \mathrm{~h}$ away from the event time limits. The chart in the bottom left corner of each diagram summarizes the distribution of storm track entry points by the corresponding Archipelago boundary section: NW - northwestern, SW - southwestern, SE - southeastern, CG - cyclogenesis (no entry point).

degraded by the Archipelago itself as they traverse it: stations farther "inland" are not affected as much. However, extratropical cyclones have the least direct effect on precipitation at the northernmost part of the Archipelago; orographic effects that enhance precipitation are believed to be especially important at this location.

Event durations varied greatly, from 4 to $168 \mathrm{~h}$. However, most events (92) lasted $72 \mathrm{~h}$ or less. The highest durations were found in the southeastern Archipelago, gradually decreasing across the Archipelago from this location. This duration information indicates a wide variation in the nature of the storms associated with high PAI. Much of this variation arises from the speed of motion of the extratropical cyclones: longer events tended to be related to slower event-related storm systems.

The timing of the high-PAI events can be used to determine whether any long-term trends are apparent. For this assessment, we grouped the PAI events at each station by decade. Results indicate that there has been no systematic increase in PAI events over the 1948-97 period as a whole. During the 1940s, 1950s, and 1960s, 3.2\%-3.6\% of all event months contained high-PAI events. In the $1970 \mathrm{~s}$, this percentage rose to a maximum of $6.2 \%$, but values dropped off again to $4.8 \%$ in the $1980 \mathrm{~s}$ and $3.0 \%$ in the 1990s. Even though this region of Canada has been experiencing recent cooling, this is not being reflected in frequencies of extreme-precipitation events.

Given the importance of such precipitation systems to forecasting and to the Canadian Archipelago's water balance, it is critical that future studies ensure they are well understood. This will require, for example, a dedicated field experiment with appropriate atmospheric and precipitation measurements upwind, over, and downwind of the variable terrain of the region. A few such studies of precipitating systems have been carried out over the southern Beaufort Sea (Hanesiak et al., 1997) or northern 


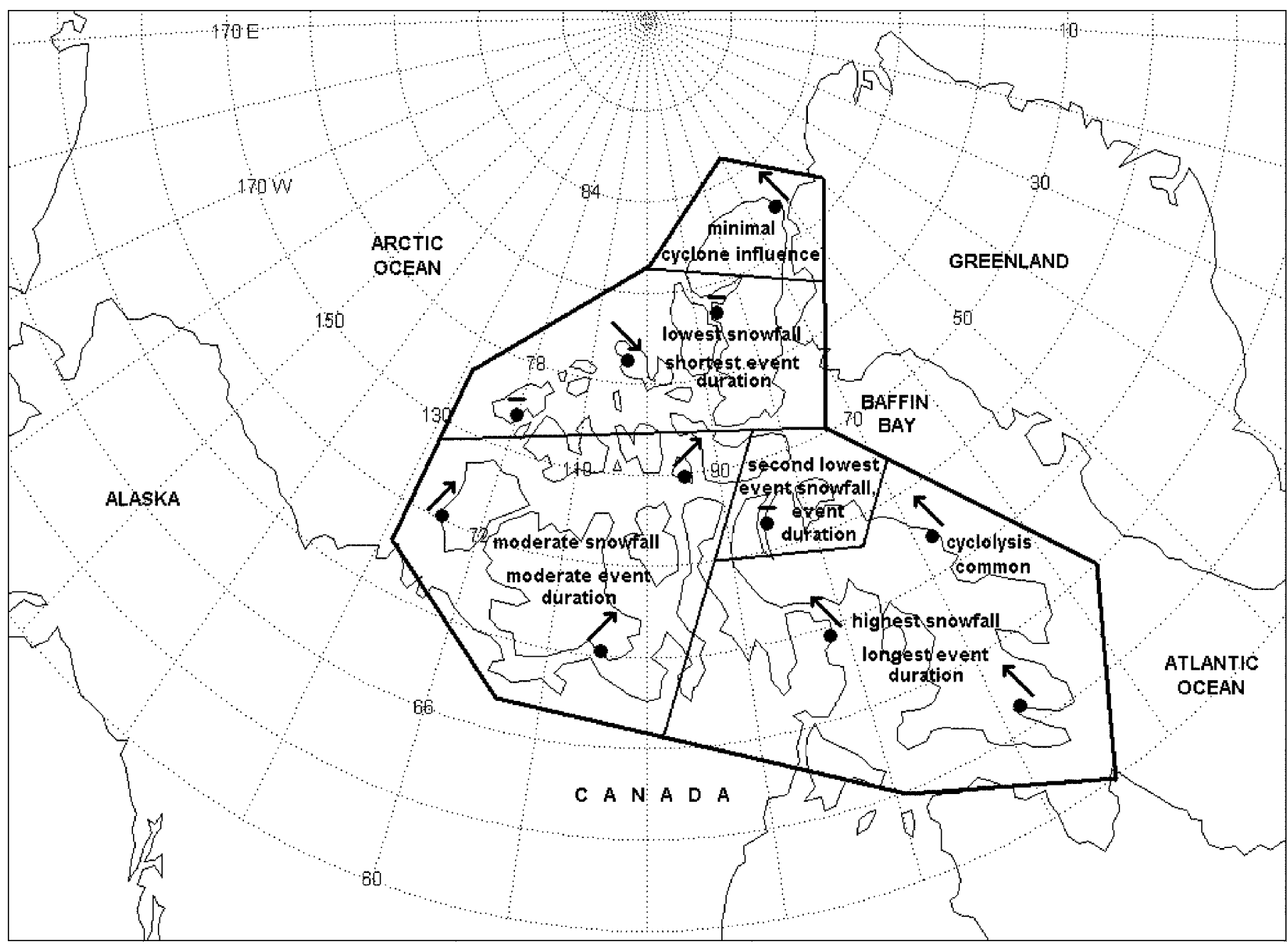

FIG. 5. Schematic diagram summarizing some major features of the cold season precipitation and extratropical cyclones that occur over the Canadian Archipelago during high-PAI events. The Archipelago is divided into five regions, each exhibiting a different set of characteristics. Snowfall refers to both event and cold-season snowfall, unless otherwise mentioned. The arrows above the stations indicate the most common entry direction for event-related cyclones, and a dash indicates that there is no preferred entry direction.

Mackenzie Basin (Asuma et al., 1998); however, the systems studied were just downwind of the western Cordillera but over flat terrain. These studies revealed some similarities to (but also some differences from) lower-latitude extratropical cyclones. For example, Szeto et al. (1997) showed that such systems can be either very efficient at converting water vapour into precipitation or very inefficient; differences arise in part from latitudinal effects on frontal structure, as well as from low-level moisture. Higher latitudes, different source regions, and distinct topography are just some characteristics of the Archipelago that lead to unique features of extratropical cyclones. These features undoubtedly affect the cyclones' ability to convert water vapour into precipitation and thereby to affect the region's role as a water vapour sink.

In summary, we have shown that a substantial amount of cold-season precipitation over the Canadian Archipelago is associated with individual events typically linked to extratropical cyclones. However, there are substantial differences in the nature, evolution, and role of these extratropical cyclones across the region.

\section{ACKNOWLEDGEMENTS}

This research was supported by the Natural Sciences and Engineering Research Council of Canada (NSERC). Thanks as well to Bob Kochtubajda for his comments on an earlier draft of this paper, and to Bob Crawford for his assistance with data collection. The comments of the reviewers have greatly improved the article.

\section{REFERENCES}

AES (ATMOSPHERIC ENVIRONMENT SERVICE). 1986. Climatic atlas: Precipitation. Downsview, Ontario: Canadian Climate Centre. 24 p.

ALT, B.T. 1978. Synoptic climate controls of mass balance variations on Devon Island Ice Cap. Arctic and Alpine Research 10(1): $61-80$.

- - - 1979. Investigation of summer synoptic climate controls on the mass balance of Meighen Ice Cap. Atmosphere-Ocean 17(3):181-199. 
- - - . 1987. Developing synoptic analogs for extreme mass balance conditions on Queen Elizabeth Island Ice Caps. Journal of Climate and Applied Meteorology 26(12):1605-1623.

ALT, B.T., and BOURGEOIS, J.C. 1995. Establishing the chronology of snow and pollen deposition events on Agassiz Ice Cap (Ellesmere Island, Northwest Territories) from autostation records. In: Current Research 1995-B, Geological Survey of Canada. 71-79.

ASUMA, Y., IWATA, S., KIKUCHI, K., MOORE, G.W.K., KIMURA, R., and TSUBOKI, K. 1998. Precipitation features observed by Doppler radar at Tuktoyaktuk, Northwest Territories, Canada during the Beaufort and Arctic Storms Experiment. Journal of Geophysical Research 126:2384-2405.

BARRY, R.G., BRADLEY, R.S., and JACOBS, J.D. 1975. Synoptic climatological studies of the Baffin Island area. In: Weller, G., and Bowling, S.A., eds. Climate of the Arctic. Fairbanks: Geophysical Institute, University of Alaska Fairbanks. 82-89.

BRADLEY, R.S., and ENGLAND, J. 1979. Synoptic climatology of the Canadian High Arctic. Geografiska Annaler 61A: $187-201$.

BROMWICH, D.H. 1997. The atmospheric moisture budget of the Arctic and Antarctic from atmospheric numerical analyses. Proceedings of the Conference on ACSYS Polar Processes and Global Climate. Rosario, Washington: World Climate Research Program. 30-32.

BRYAZGIN, N.N. 1976. Yearly mean precipitation in the Arctic region accounting for measurement errors (in Russian). Proceedings: Arctic and Antarctic Research Institute 323: 40-74.

BURNS, B.M. 1973. The climate of the Mackenzie Valley Beaufort Sea. Climatological Studies 24, Vol 1. Downsview, Ontario: Atmospheric Environment Service. 227 p.

- - - 1974. The climate of the Mackenzie Valley - Beaufort Sea. Climatological Studies 24, Vol 2. Downsview, Ontario: Atmospheric Environment Service. 239 p.

CURRY, J.A., ROSSOW, W.B., RANDALL, D., and SCHRAMM, J.L. 1996. Overview of Arctic cloud and radiation characteristics. Journal of Climate 9:1731-1764.

GULLETT, D.W., SKINNER, W.R., and VINCENT, L. 1992. Development of a historical Canadian climate database for temperature and other climate elements. Climatological Bulletin 26:125-131.

HANESIAK, J.M., STEWART, R.E., SZETO, K.K., HUDAK, D.R., and LEIGHTON, H.G. 1997. The structure, water budget and radiational features of a high latitude warm front. Journal of Atmospheric Science 54:1553-1573.

HOLTON, J.R. 1992. An introduction to dynamic meteorology. 3rd ed. San Diego, California: Academic Press Inc.

KALNAY, E., KANAMITSU, M., KISTLER, R., COLLINS, W., DEAVEN, D., GANDIN, L., IREDELL, M., SAHA, S., WHITE, G., WOOLLEN, J., ZHU, Y., CHELLIAH, M., EBISUZAKI,
W., HIGGINS, W., JANOWIAK, J., MO, K.C., ROPELEWSKI, C., WANG, J., LEETMAA, A., REYNOLDS, R., JENNE, R., and JOSEPH, D. 1996. The NCEP/NCAR 40-year reanalysis project. Bulletin of the American Meteorological Society 77: 437-478.

LACKMANN, G.M., and GYAKUM, J.R. 1996. The synoptic and planetary-scale signatures of precipitating systems over the Mackenzie River basin. Monthly Weather Review 126: 668-691.

LOUIE, P.Y.T., HOGG, W.D., MACKAY, M.D., ZHANG, X., and HOPKINSON, R.F. 2002. The water balance climatology of the Mackenzie Basin with reference to the 1994-95 water-year. Atmosphere-Ocean 40:159-180.

MAXWELL, B. 1980. The climate of the Canadian Arctic Islands and adjacent waters. Climatological Studies 30, Vol. 1. Downsview, Ontario: Atmospheric Environment Service. 531 p.

- - - 1982. The climate of the Canadian Arctic Islands and adjacent waters. Climatological Studies 30, Vol. 2. Downsview, Ontario: Atmospheric Environment Service. 589 p.

MEKIS, E., and HOGG, W.D. 1999. Rehabilitation and analysis of Canadian daily precipitation time series. Atmosphere-Ocean 37(1):53-85.

METCALFE, J.R., ISHIDA, S., and GOODISON, B.E. 1994. A corrected precipitation archive for the Northwest Territories. In: Environment Canada - Mackenzie Basin Impact Study, Interim Report No. 2. 110-117.

SERREZE, M.C. 1995. Climatological aspects of cyclone development and decay in the Arctic. Atmosphere-Ocean 33: $1-23$.

SERREZE, M.C., and MASLANIK, J.A. 1997. Arctic precipitation as represented in the NCEP/NCAR reanalysis. Annals of Glaciology 25:429-433.

SERREZE, M.C., BOX, J.E., BARRY, R.G., and WALSH, J.E. 1993. Characteristics of Arctic synoptic activity, 1952-1989. Meteorological and Atmospheric Physics 51:147-164.

SERREZE, M.C., BARRY, R.G., and WALSH, J.E. 1995. Atmospheric water vapor characteristics at $70^{\circ} \mathrm{N}$. Journal of Climate 8:719-731.

STEWART, R.E., BACHAND, D., DUNKLEY, R.R., GILES, A.C., LAWSON, B., LEGAL, L., MILLER, S.T., MURPHY, B.P., PARKER, M.N., PARUK, B.J., and YAU, M.K. 1995. Winter storms over Canada. Atmosphere-Ocean 33:223-247.

SZETO, K.K., STEWART, R.E., and HANESIAK, J.M. 1997. High latitude cold season frontal cloud systems and their precipitation efficiency. Tellus 49:439-454.

WHITTAKER, L.M., and HORN, L.H. 1984. Northern Hemisphere extratropical cyclone activity for four mid-season months. Journal of Climatology 4:297-310.

WOO, M.R., HERON, R., MARSH, P., and STEER, P. 1983. Comparison of weather station snowfall with winter snow accumulation in High Arctic basins. Atmosphere-Ocean 21: $312-322$. 